Available online at JECE (Journal of Early Childhood Education)

Website: http://journal.uinjkt.ac.id/index.php/jece

Permalink/DOI: http://dx.doi.org/10.15408/jece.v1i2.13693

JECE, 1 (2), Desember 2019, 9-15

\title{
PENINGKATAN KEPERCAYAAN DIRI ANAK MELALUI PERMAINAN KUCING DAN TIKUS DI TK SAYANG IBU TAHUN 2019
}

\author{
Hinggil Permana, Rina Syafrida \\ Universitas Singaperbangsa Karawang \\ Corresponding e-mail: rina.syafrida@fai.unsika.ac.id \\ hinggil.permana@fai.unsika.ac.id
}

\begin{abstract}
This research is conducted to improve children's confidence in TK Sayang Ibu, Bekasi. This research uses action research method. The research subjects consisted of 8 boys and 12 girls, the research procedure is carried out in 2 cycles with 3 meetings in each cycle. The result shows that the kucing dan tikus game can increase the confidence of children of group $A$ in TK Sayang Ibu. The increment happens from first cycle 53,43\% to second cycle 77,5\%.
\end{abstract}

Keywords: Confidence, Games, Early Childhood

\begin{abstract}
Abstrak
Penelitian ini dilakukan untuk meningkatkan kepercayaan diri anak di TK Sayang Ibu, Bekasi. Penelitian ini menggunakan metode action research. Subjek penelitian terdiri dari 8 orang anak laki-laki dan 12 orang anak perempuan, prosedur penelitian ini dilaksanakan sebanyak 2 siklus dengan 3 kali pertemuan pada setiap siklusnya. Hasil penelitian menunjukkan penggunaan permainan kucing dan tikus dapat meningkatkan kepercayaan diri anak kelompok A di TK Sayang Ibu. Peningkatan terjadi pada siklus I sebesar 53,43 \% dan siklus II menjadi 77,5\%.
\end{abstract}

Kata Kunci: Kepercayaan diri, Permainan, Usia Dini 


\section{Pendahuluan}

Usia dini merupakan rentang usia yang sangat sensitif dalam masa perkembangan seorang anak. Keberlangsungan kehidupan dan perkembangan anak pada masa mendatang tergantung dari pengalaman dan stimulasi yang ia peroleh pada masa usia dini. Oleh sebab itu tidak berlebihan jika sebagian ahli berpendapat bahwa usia dini merupakan usia emas perkembangan anak atau dikenal dengan golden age karena pada usia ini otak anak berkmabang hampir 80 persen, sisanya baru setelah ia remaja.

Pada tahapan ini terbentuknya dasar pertama dalam mengembangkan kemampuan penginderaan, kognitif, fisik, bahasa, sosial emosional, konsep diri, disiplin, kemandirian, seni, moral, dan nilai-nilai agama, sehingga dapat dikatakan bahwa sikap, kebiasaan dan perilaku yang dibentuk selama 5 tahun pertama sangat menentukan bagaimana cara seseorang beradaptasi, berinteraksi dan bersosialisasi dalam lingkungannya ketika ia dewasa. Oleh sebab itu dibutuhkan kondisi dan stimulasi-stimulasi yang sesuai dengan kebutuhan anak agar pertumbuhan dan perkembangan anak tercapai secara optimal. Usia dini merupakan masa peka bagi anak, pada usia ini anak mulai sensitif untuk menerima berbagai upaya perkembangan seluruh potensi anak. Anak usia dini biasanya akan menerapkan apa yang mereka lihat dan rasakan dari lingkungannya. Apa saja yang telah mereka dapatkan ketika masih kecil akan membekas sangat kuat dalam ingatan mereka hingga mereka dewasa. Oleh sebab itu orang dewasa merupakan model bagi anak, sebagai model orang dewasa harus dapat menjaga sikap, tutur kata dalam berinteraksi dengan anak agar anak tidak mencontoh model yang salah.

Kesuksesan seorang anak yang akan datang tidak hanya ditentukan oleh seberapa pintar diri seseorang, melainkan lebih banyak tergantung kepada seberapa besar kita mampu beradaptasi, bersosialisasi dan berinteraksi dengan lingkungan. Daniel Golemen (Shoni, Amrozi, \& Pd, n.d.) menyatakan bahwa kesuksesan dan keberhasilan dalam menjalin kehidupan sangat dipengaruhi oleh kecerdasan emosional $80 \%$ dan $20 \%$ dipengaruhi oleh kecerdasan intelektual, kecerdasan emosional bukanlah kecerdasan statis yang diperoleh karena "warisan" orang tua, namun kecerdasan emosi dapat tumbuh dan berkembang dengan belajar. Masa terbaik untuk dapat memaksimalkan perkembangan kualitas emosional adalah pada usia dini sehingga anak terbiasa dalam mengontrol kondisi emosionalnya hingga ia dewasa kelak dan akan tumbuh menjadi pribadi yang memiliki kecerdasan emosional yang bagus.

Namun fenomena yang peneliti temui di lapangan bertolak belakang dengan keadaan yang seharusnya. Dari 20 anak berusia 3 sampai 6 tahun yang diteliti di TK Sayang Ibu dari aspek kepercayaan diri, fenomena yang peneliti temui di lapangan adalah beberapa anak masih belum terlihat kepercayaan dirinya, hal ini terlihat ada 
anak yang masih malu tidak mau bergaul dengan teman sebayanya dan takut untuk maju ke depan kelas. Tidak hanya itu, pada saat jam bermain bebas, ada anak yang tidak mau berpisah dari ibunya. Fenomena lain juga terlihat yang terkait dengan aspek sosial anak yaitu sebagian anak belum bisa membaur dengan seluruh anak. Saat bermain di luar kelas beberapa orang anak tidak mau bergabung bermain dengan anak lain, mereka lebih memilih berkelompok di dalam kelas.

Selama ini kegiatan pembelajaran di taman kanak-kanak (TK) hanya difokuskan pada aspek kognitif dan bahasa saja, setiap hari guru mengajarkan anak membaca, menulis dan berhitung agar kelak saat anak lulus dari TK mereka sudah dapat membaca dengan lancar dan berhitung dengan baik sehingga dapat diterima di SD yang mereka inginkan. Namun ada hal penting yang dilupakan oleh guru, tidak hanya aspek kognitif dan bahasa saja yang harus distimulasi, tapi ada aspek lain yang lebih penting yaitu aspek sosial emosional. Aspek inilah yang akan menentukan kepribadian anak dimasa mendatang, bagaimana ia mengontrol emosinya, bagaimana ia bersosialisasi dengan masyarakat serta bagaimana ia bisa bertahan menghadapi tantangan pada masa mendatang. Selain itu guru kurang kreatif dalam mendesain kegitan pembelajaran yang menyenangkan bagi anak, guru hanya terpaku pada LKS dalam kegiatan sehari-hari, padahal sebenarnya banyak permainan sederhana yang mengandung unsur pembelajaran serta menyenangkan bagi anak.

Terinspirasi dari penelitian sebelumnya yang menyatakan bahwa permainan dapat meningkatkan kemampuan motorik kasar dan kognitif anak usia dini (Gustiana, 2011), maka dilakukan penelitian menggunakan media permainan kucing dan tikus untuk meningkatkan kecerdasan sosial emosional khususnya kepercayaan diri pada anak usia dini. Permainan kucing dan tikus merupakan permainan yang melibatkan banyak anak dan menuntut anak untuk bekerjasama dengan anak lain selama permainan berlangsung. Permainan ini juga akan menimbulkan kegembiraan serta ketegangan bagi anak saat melihat anak yang memerankan tikus dikejar oleh anak yang berperan sebagai kucing. Selain itu anak lain yang menjadi pagar, melindungi tikus agar tidak tertangkap oleh kucing.

\section{Kepercayaan Diri Anak}

Salah satu hal yang berkaitan langsung dengan kecerdasan sosial emosional anak adalah dilihat dari kepercayaan diri anak tersebut (Anwar, 2016). Kepercayaan diri merupakan sebuah keyakinan diri yang tertanam dalam diri masing-masing individu untuk berprilaku sesuai dengan citra diri yang akan dibangun oleh individu tersebut (Bandura, 1977). Selain itu, kepercayaan diri merupakan kondisi mental atau psikologis individu untuk dapat mengevaluasi keseluruhan dirinya sehingga memberikan keyakinan kuat pada kemampuan dirinya untuk melakukan 
tindakan dalam melakukan tindakan untuk mencapai keinginannya (Rohmah, 2018). Bermain tidak sekedar mengisi waktu, tetapi merupakan suatu kebutuhan seperti halnya makanan, perawatan, dan cinta kasih. Anak memerlukan berbagai variasi mainan untuk kesehatan fisik, mental dan perkembangan emosinya. Melalui bermain anak tidak hanya menstimulasi perkembangan otot-ototnya, tetapi lebih dari itu anak tidak sekedar melompat, melempar atau berlari. Tetapi mereka bermain dengan menggunakan seluruh emosinya, perasaannya dan pikirannya. Kesenangan merupakan salah satu elemen pokok dalam bermain. Anak akan bermain selama aktivitas tersebut mengiburnya, pada saat mereka bosan mereka akan berhenti bermain.

\section{Permainan Kucing dan Tikus}

Bermain bukan berarti membuang-buang waktu, juga bukan berarti membuat anak menjadi sibuk sementara orang tuanya mengerjakan pekerjaannya sendiri. Tetapi anak akan menemukan kekuatan dan kelemahannya sendiri, minatnya, cara menyelesaikan tugas-tugas dalam bermain dan lain-lain. Bermain adalah unsur yang penting untuk perkembangan anak baik fisik, emosi, mental, intelektual, kreativitas dan sosial. Anak yang mendapat kesempatan cukup untuk bermain akan menjadi orang dewasa yang mudah berteman, kreatif dan cerdas, bila dibandingkan dengan mereka yang masa kecilnya kurang mendapat kesempatan bermain. Permainan kucing dan tikus merupakan sebuah permainan yang bertujuan untuk mengembangkan kecerdasan sosial emosional anak. Caranya anak-anak berpegangan membentuk lingkaran kemudian si tikus ada di dalam dan si kucing berada di luar lingkaran. Anak-anak akan menjalankan tugasnya masing-masing. Tugas tikus berlari agar kucing tidak menangkapnya, sedangkan tugas kucing adalah mengejar si tikus sampai dapat.

Permainan kucing dan tikus ini merupakan jenis permainan tanpa alat dan media. Artinya permainan ini lebih cendrung menggunakan aktivitas fisik sebagai kegiatan bermain, seperti berlari, melompat dan meloncat (Marliza, 2018:1). Permainan ini memberikan rasa senang karena anak membarikan energi dalam berlari. Adapun aturan permainan ini adalah satu anak berperan sebagai tikus yang berada dalam kurungan, kurungannya adalah anak-anak lain yang bergandengan tangan menjadi lingkaran. Satu anak lain berperan sebagai kucing. Kucing berusaha menangkap tikus yang ada dalam kurungan. Kucing dapat berkeliling kandang sambil menggapai tikus. Anak-anak yang menjadi kurungan berusaha menolong tikus dengan berbagai cara (Nugraha, 2013;203). Keunggulan permainan kucing dan tikus adalah (a) Anak dapat belajar berinteraksi dengan orang lain yaitu teman sepermainan kelompoknya. (b) Anak dapat mempelajari peran ataupun tanggung jawab yang diberikan kepadanya. (c) Anak akan berusaha agar ia diterima oleh teman bermainnya. (d) Anak akan berusaha menyesuaikan diri dengan aturan- 
aturan yang telah ditetapkan. (e) Anak akan berusaha jujur dan bersikap ramah dengan teman (f) Anak dapat bermain secara kelompok dan membangun kerjasama dengan anak lain.

\section{Metode}

Jenis penelitian yang dilaksanakan adalah penelitian tindakan kelas (Classroom Action Research). Dalam pelaksanaan penelitian tindakan kelas ini, metode penelitian mengacu pada model Kurt Lewin (1946) yang menyatakan bahwa dalam satu siklus terdapat empat tahapan yaitu perencanaan, tindakan, observasi dan refleksi. Sebelum masuk ke siklus I, terlebih dahulu melakukan tindakan berupa identifikasi masalah. Pada siklus II, refleksi yang sudah dilakukan di siklus I, digunakan pada perencanaan siklus II. Subjek penelitian ini adalah anak pada TK Sayang Ibu, pada kelas B sebanyak 20 orang anak pada semester ganjil (satu) tahun pelajaran 2018/2019, yang terdiri dari 8 orang laki-laki dan 12 orang perempuan.

\section{Hasil dan Pembahasan}

Berdasarkan hasil analisis data yang telah dilakukan dengan menggunakan permainan tradisional kucing dan tikus dapat memberikan pengaruh positif terhadap kepercayaan diri anak. Analisis data kuantitatif didapatkan dari hasil pelaksanaan penelitian dari pra-tindakan sampai pada siklus I dan II secara kuantitatif hasil data-data pengamatan kepercayaan diri anak melalui permainan tradisional kucing dan tikus yang dapat dilihat sebagai berikut:

Tabel. 1

Hasil kenaikan pra penelitian, siklus I dan siklus II

\begin{tabular}{|l|l|l|l|l|l|c|c|c|c|c|c|}
\hline \multicolumn{2}{|c|}{ Subjek } & \multicolumn{2}{c|}{ Pra Tindakan } & \multicolumn{2}{c|}{ Siklus I } & \multicolumn{2}{c|}{ Point } & \multicolumn{2}{c|}{ Siklus II } & \multicolumn{2}{c|}{ Poin } \\
\hline No & Nama & Skor & $\%$ & Skor & $\%$ & Kenaikan & $\%$ & Skor & $\%$ & Kenaikan & $\%$ \\
\hline 1 & AM & 18 & 28.12 & 35 & 54.68 & 17 & 26.56 & 51 & 79.68 & 16 & 25 \\
\hline 2 & AP & 16 & 25 & 30 & 46.87 & 14 & 21.87 & 45 & 70.31 & 13 & 23.43 \\
\hline 3 & HL & 20 & 31.25 & 38 & 59.37 & 18 & 28.125 & 57 & 89.06 & 19 & 29.68 \\
\hline 4 & MA & 16 & 25 & 27 & 42.18 & 11 & 17.18 & 39 & 60.93 & 12 & 18.75 \\
\hline 5 & TA & 22 & 34.37 & 41 & 64.06 & 19 & 29.68 & 56 & 87.5 & 15 & 23.43 \\
\hline \multicolumn{1}{|l|}{ Jumlah } & 92 & 28.75 & 171 & 53.43 & 79 & 24.68 & 248 & 77.5 & 77 & 24.06 \\
\hline
\end{tabular}

Tabel diatas menunjukan bahwa permainan tradisional pada anak dari pratindakan sampai pada siklus II mengalami peningkatan yang lebih baik. Kepercayaan diri anak meningkat setelah dilakukannya tindakan pada siklus I dengan rata-rata peningkatan sekitar 24,68\% kemudian meningkatkan kembali setelah dilakukannya tindakan pada siklus II dengan rata-rata kenaikan sebanyak $24,06 \%$ dari siklus I. Jika divisualisasikan dalam diagram dapat digambarkan sebagai berikut:

Diagram I 


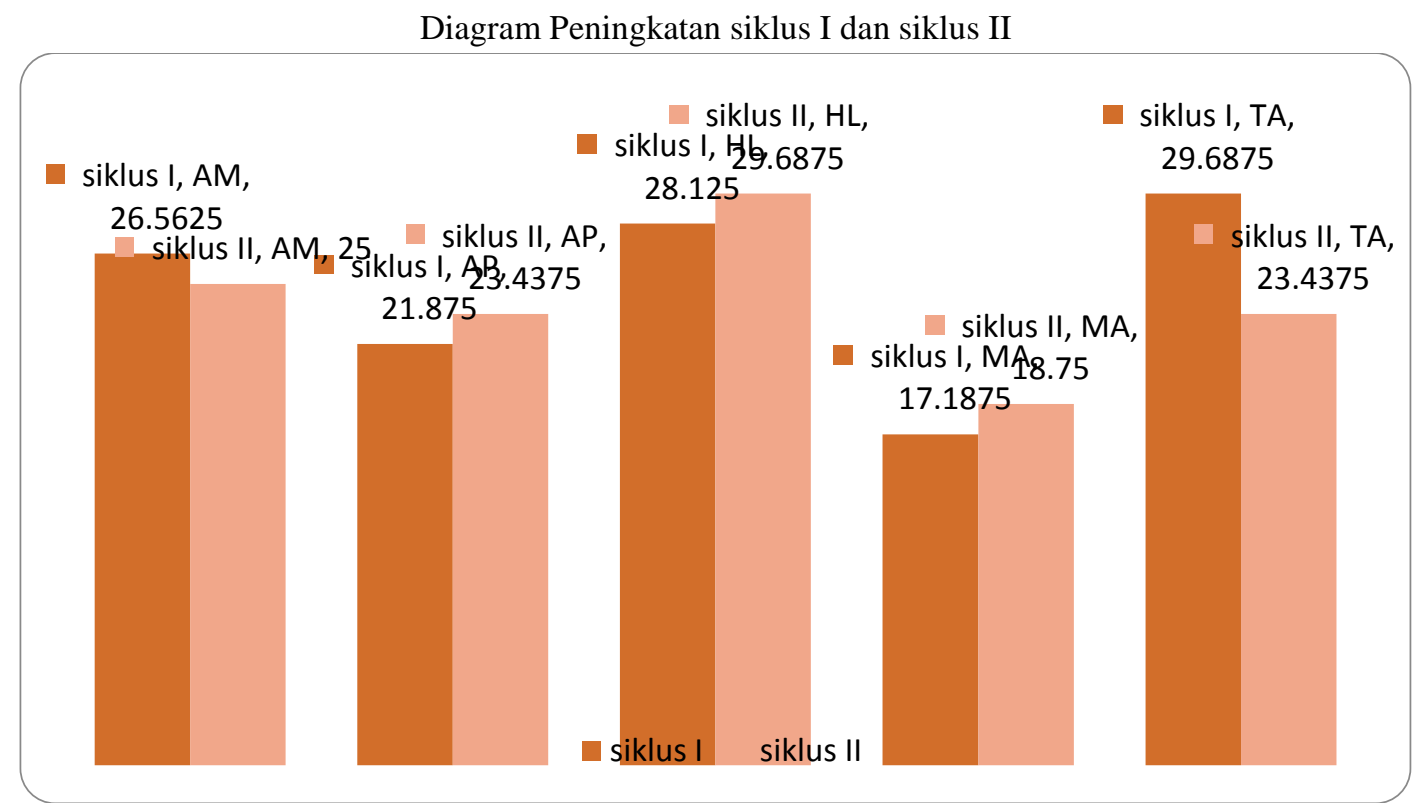

Dari diagram diatas terlihat adanya peningkatan kepercayaan diri anak setelah diadakannya tindakan siklus I dan siklus II. Responden 1 mengalami peningkatan $26,5625 \%$ dari siklus I, kemudian meningkat $25 \%$ pada siklus II. Responden 2 mengalami peningkatan 21,875\% dari siklus I, kemudian meningkat $23,4375 \%$ pada siklus II. Responden 3 mengalami peningkatan 28,125\% pada siklus I, kemudian meningkat 29,6875\% pada siklus II. Responden 4 mengalami peningkatan $17,1875 \%$ dari siklus I, kemudian meningkat 18,75\% pada siklus II. Responden 5 mengalami peningkatan 29,6875\% dari siklus I, kemudian meningkat 23,4375\% pada siklus II. Peningkatan persentase dari pra-tindakan sampai pada siklus II tersebut menunjukan bahwa dengan permainan kucing dan tikus pada anak menunjukkan kepercayaan diri anak kelompok A meningkat.

Indikator keberhasilan dari tindakan dalam penelitian ini terjadi dengan peningkatan kepercayaan diri pada anak kelompok A. Hasil dari penelitian ini menunjukan bahwa dengan permainan kucing dan tikus dapat meningkatkan kepercayaan diri anak kelompok A. Kepercayaan diri anak mengalami peningkatan dari pra-tindakan, siklus I dan siklus II. Peningkatan tersebut ditandai dengan skor yang telah diperoleh semua anak pada observasi II yakni semua responden telah tuntas pada tingkat kecerdasan sosial emosional. Hal tersebut dapat dilihat pada persentase responden paling rendah $17,1875 \%$ meningkat sebesar 18,75\% sehingga persentase kepercayaan diri anak mencapai $77,5 \%$ pada siklus akhir.

Hasil penelitian mengenai kepercayaan diri anak di TK Sayang Ibu yang di lakukan melalui permainan kucing dan tikus dapat di simpulkan yaitu melalui penggunaan permainan kucing dan tikus dapat meningkatkan kepercayaan diri anak kelompok A di TK Sayang Ibu. Hal ini sesuai dengan pengamatan yang telah di lakukan pada anak mulai dari siklus I sampai siklus II dan terjadi peningkatan disetiap siklusnya yaitu rata-rata siklus I 53,43 \% meningkat $24,06 \%$ pada siklus II 
menjadi $77,5 \%$. Permainan kucing dan tikus memberikan kesempatan pada anak untuk berinteraksi dengan anak lain secara verbal dan nonverbal, anak dituntut untuk berkomunikasi secara aktif dan menjalin kerjasama dengan anak lain. Selain itu melalui permainan kucing dan tikus anak dapat bersosialisasi dengan anak lain menggunakan bahasa yang sederhana.

\section{Simpulan}

Hasil penelitian mengenai peningkatan kepercayaan diri anak di TK Sayang Ibu yang di lakukan melalui permainan kucing dan tikus dapat di simpulkan yaitu melalui permainan kucing dan tikus dapat meningkatkan kepercayaan diri anak kelompok A di TK Sayang Ibu. Hal ini sesuai dengan pengamatan yang telah di lakukan pada anak mulai dari siklus I sampai siklus II dan terjadi peningkatan disetiap siklusnya yaitu rata-rata siklus I sebesar $53,43 \%$ meningkat $24,06 \%$ pada siklus II menjadi 77,5\%.[]

\section{Daftar Rujukan}

Anwar, Y. (2016). "Pengaruh Kecerdsan Emosional dan Kepercayaan Diri Terhadap Personal Value Serta Dampaknya Terhadap Pemahaman Akuntansi Keuangan", Media Riset Akuntansi, Auditing Dan Informasi, 383.

Bandura, A. (1977). "Self-efficacy: Toward a unifying theory of behavioral change", Psychological Review.

Gustiana, A. D. (2011). "Pengaruh Permainan Modifikasi Terhadap Kemampuan Motorik Kasar Dan Kognitif Anak Usia Dini", Jurnal Penelitian Pendidikan, Edisi Khus (2).

Marliza, dkk. 2018. "Pengaruh Penerapan Permainan Tradisional Kucing Dan Tikus Terhadap Kemampuan Motorik Kasar Anak Usia 4-5 Tahun Di Tk Negeri Pembina 3 Pekanbaru", Jurnal Online Mahasiswa Fakultas Keguruan dan Ilmu Pendidikan, Vo. 5 No.1.

Nugraha, Bayu. 2013. "Permainan kretif untuk anak usia dini", Jurnal Pedidikan Anak Vol. 2, No. 1.

Rohmah, J. (2018). "Pembentukan Kepercayaan Diri Anak Melalui Pujian", Martabat: Jurnal Perempuan Dan Anak, Vol. 2, No. 1.

Shoni, O., Amrozi, R., \& Pd, M. I. (n.d.). Pemikiran Daniel Goleman. 